\title{
Nature Tourism and Mobile Applications: Düzce Province Example
}

\author{
Doğa Turizmi ve Mobil Uygulamalar: Düzce İli Örneği
}

\author{
Dr. Zülkif DAĞLI \\ Governor of Düzce Camikebir District \\ E-posta: zulkifdagli@hotmail.com
}

\begin{abstract}
Nowadays, consumers benefit from the opportunities provided by technology, especially when selecting a destination in the tourism sector. The time constraints of people and the opportunities provided by technology are among the most important factors of the increase in consumers' preference in recent years. The aim of this study is to examine mobile applications, which is one of the digital studies for nature tourism in Düzce province. In the first part of the study, the concept of nature tourism was examined within the scope of the conceptual framework and then the mobile application was created in the province of Düzce. The data for the purpose of the study were carried out by case study method, which is one of the qualitative research methods. In the results of the research, it is seen that the mobile applications developed in order to raise awareness within the scope of nature tourism in Düzce have come to the forefront with technology.
\end{abstract}

Key Words: Nature tourism, Mobile applications, Düzce

\section{Öz}

Günümüzde tüketiciler özellikle turizm sektöründe bir destinasyonu tercih ederken teknolojinin sağlamış olduğu imkanlardan yararlanmaktadır. İnsanların zaman kısıtının olması ve teknolojinin sağladığı imkanlar tüketicilerin son yıllardaki bu tercihlerdeki artışın en önemli etkenleri arasındadır. Bu çalışmanın amacı, Düzce ilinde doğa turizmine yönelik yapılmış olan dijital çalışmalardan biri olan mobil uygulamalarını incelemektir. Çalışmada ilk olarak kavramsal çerçeve kapsamında doğa turizmi kavramına daha sonra da Düzce ilinde oluşturulmuş mobil uygulamasına yer verilmiştir. Araştırmanın amacına yönelik veriler ise nitel araştırma yöntemlerinden biri olan örnek olay yöntemi ile gerçekleştirilmiştir. Araştırma sonuçlarında, Düzce ili doğa turizmi kapsamında farkındalık oluşturabilmek amacıyla geliştirilmiş mobil uygulamaların teknoloji ile ön plana çıktığı görülmektedir.

Anahtar Kelimeler: Doğa turizmi, Mobil uygulamalar, Düzce 


\section{Introduction}

One of the most important factors affecting the economic and cultural dimension of globalization is rapid changes in technology. With the changes in technology, communication tools have also gained a different dimension. Extensive use of social media up to the degree of admiration nowadays and so the occurrence of different interest areas in social media and the emergence of different social media channels can be given as examples. With the transition to the information age we are in, the use of technology has started to appear in every field. It tries to satisfy the curiosity of people from their places to different countries or cities even for a short time, thanks to a short virtual tour with computer or smart phones. All the activities that can be done in a destination or all of those that are awakening curiosity about a place are now available at the touch of a button or an application, which saves time and becomes more attractive (Zelan, 2015: 1). Virtual technology or digital (mobile) applications, which make human life more liveable and one of the benefits of modern technology to keep up with modern living conditions, have pushed many sectors such as medicine, engineering, landscape, construction, health and tourism sectors to make technologyoriented studies. Especially in the service-oriented sectors, the development of the virtual tour has started to be used to generate interest and curiosity among internet users and potential customers. With the projection of three-dimensional panoramic images, virtual tour technology has started to be used in the promotion of destinations (Durmaz, et al., 2018: 33).

In recent years, it has become inevitable that destinations should turn to technological and innovative activities. Especially the provinces or destinations that come to the forefront with the tourism sector should be able to raise awareness in order to achieve sustainability and competitive advantage. In order to increase its tourism potential, Düzce has turned to different applications that are technology-based, attractive and reachable by everybody. In this context, a mobile application with the theme of nature tourism has been created for Düzce province that can attract the attention of especially nature lovers.

The aim of this study is to examine the mobile application for nature tourism in Düzce. In the study, nature tourism is defined in the conceptual framework with the help of secondary data and then the mobile application prepared in Düzce province is included.

\section{Nature Tourism}

Nature, which is one of the most important attraction elements of tourism destinations, is also one of the motives that direct people to travel. Nature is known as the reason to travel from the moment human beings exist. The reason for this is the desire to find food for the survival of mankind. Today, this travel motivation has been replaced by new travel motivations such as natural beauties and cultural attractions. Issues such as the discovery and presentation of nature as a product and preservation of nature due to its importance in tourism activities have attracted the attention of researchers as an important research subject for many years. It is noteworthy that in recent years this important attraction has been handled with different marketing techniques and different approaches depending on the policies in the balance of 'protection and use of nature'. Therefore, nature tourism is generally carried out with sustainability policies (Akoglan Kozak and Bahce, 2012: 170). 
Nature tourism is a type of tourism that has turned its face to nature. It is defined as action or actions that are satisfying in terms of the visitors' admiration, having the purpose of mental and physical renewal, at the same time including the individual's social, cultural, physical, spiritual and economic opportunities and their dependent free time (Korkmaz, 2001: 12).

According to Ozkan (1995), nature tourism is defined as a measured, environmentally sensitive and respectful tourism policy aiming at transferring the current tourism recreational resources to the next generations with the way of increasing respect and sensitivity to the environment. Nature tourism appears as some holiday and recreation activities in natural resources. It includes all forms of tourism related to the use of natural resources such as landscape integrity, topography, water, vegetation and wildlife. Nature-based tourism includes recreational and adventure sport activities done in rural areas.

Nature-based tourism types can be categorized as river tourism, botanical tourism, mountain and winter sports tourism, agricultural tourism, bird watching, plateau tourism, health (thermal and SPA) tourism and air sports tourism. With its unique nature, Düzce province is able to offer many of the nature-based tourism types to existing and potential participants. Mobile applications have been developed to announce the natural beauty of Düzce not only to a certain segment but to the whole world. The province of Düzce, which is open to development and information, did not remain indifferent to the developments in the virtual media and started to use various technological infrastructure and applications in both tourism and other sectors in order to utilize the opportunities arising from the developments in this field.

\section{Mobile Application}

Withe many changes in the field of technology today, the period of mobile era has been entered in global sense. In parallel to this, changes in mobile applications are seen in all sectors. In parallel to this, the needs and demands of consumers are changing in line with mobile developments. Technological environment is an important factor in purchasing and decision making.

"Mobile devices and mobile applications provide businesses with benefits that go beyond the opportunity to have a new channel to reach their customers without using the vehicle. This rapid development in information technologies and telephony functions in recent years, coupled with the incredible increase in the number of mobile phone users", has resulted in mobile applications in destination marketing (Surucu and Bayram, 2016: 2025).

It is seen that "Mobile Applications" started to function in the form of digitalization in the tourism sector as in every sector in the world and in our country (Sanlı Oz et al., 2013: 251). Especially in the tourism sector, digitalization has started to show itself to a great extent. In addition to this, it is seen that important tourism destinations have also started to use mobile applications. Destinations that use these applications will achieve significant competitive advantage over other destinations (Aslan and Aslan: 2013: 86).

Gulbahar and Yıldırım (2015: 453) stated that the use of mobile applications in tourism provides both enterprises to keep up with innovations and to bring enterprises to the forefront in marketing. Mobile applications constitute a different dimension in social media marketing. In particular, the content of mobile applications to be created 
in terms of tourism enterprises should be prepared in a way to meet the demands and expectations of users.

When examined in another dimension, mobile applications are also used in the public sector. These practices, which have come to the forefront in the e-government system, have been made in order to provide more services and easier accessibility to the citizens of governments and they have equal access rights (Serra, et al., 2015: 349). Mobile applications dominate in the guiding dimension of tourism. Irmanti, et al., (2017: 556) discusses in her study mobile guide applications for tourism in Indonesia.

In the tourism sector, virtual guidance applications and mobile applications of hotels both increase the innovative activities of the enterprises and ensure their sustainable competition. With the development of Information Technology and Transportation, new countries and regions have started to be discovered and with this, tourism activities have increased. It is necessary to ensure continuity of the use of tourism resources by transferring them to the future without causing too much damage to the values of Tourism. The use of these resources in conjunction with today's digital activities will contribute significantly to the enterprises.

\section{Düzce Mobile Application}

In this section, information about Düzce mobile application will be presented. Düzce mobile application works on Android and iOS platforms. Within the application, walking routes, cycling routes, jeep safari routes, Motor Sports routes, Horse riding trails, Climbing and Paddle routes can be reached under the Trails and Routes menu. If the "Run Map without Internet" tab is activated in any route from Trails and Routes, it will load the map of the region where the course is located to your mobile. Thanks to loaded map into the mobile, Trails and Routes can be used without internet, where the GSM network cannot send signals. Düzce mobile application is the first and only offline working application in the field of trekking. It attracts the attention of especially walking groups. Thanks to the offline operation feature, walking groups can find their way safely without getting lost, searching for signboard and marking. The length of the course, difficulty status, structure of the course, course notes, course description, video, 360tr panoramic virtual tours, activities that can be done (camping, picnic, etc.), characteristics of the course (drinkable water, landscape, toilet etc.) are also located under the courses. Places with tourist value are located under "Navigable Places" menu within Düzce Mobile Application.

Under this menu, lakes, waterfalls, plateaus, national parks, historical sites, caves, mosques, shrines, picnic and promenade areas can be reached. Also, directions to these areas can be obtained from the application. As with Trails and Routes, activities, features, descriptive information is also available here. Many pictures and videos about each destination can be reached. 360 degree panoramic photo can be seen with VR glasses. Again, there is a system of appreciation (stars) about the destinations. Within the Düzce mobile application, Düzce University menu has been created in order to help the students coming from outside of Düzce. Under this menu, access to contact information and videos of Institutes, Faculties, Schools, and Vocational Schools can be reached and those who want to go to these places can get directions from the application. Within the Düzce mobile application, Organized Industrial Sites menu has been created in order to provide convenience for those coming to Düzce from outside for business purposes. Under this menu, the contact information of the companies located in Düzce OSB I, Düzce OSB II and Düzce Gümüşova OSB can be displayed and directions can be obtained for transportation to 
these factories. Business are also included in this application. In Düzce mobile application, the list of organizations under Civil Administrations, Local Administrations and Subsidiary Institutions can be accessed and directions can be obtained under the Official Institutions menu.

\section{Picture 1: Düzce Mobile Application Main Page}

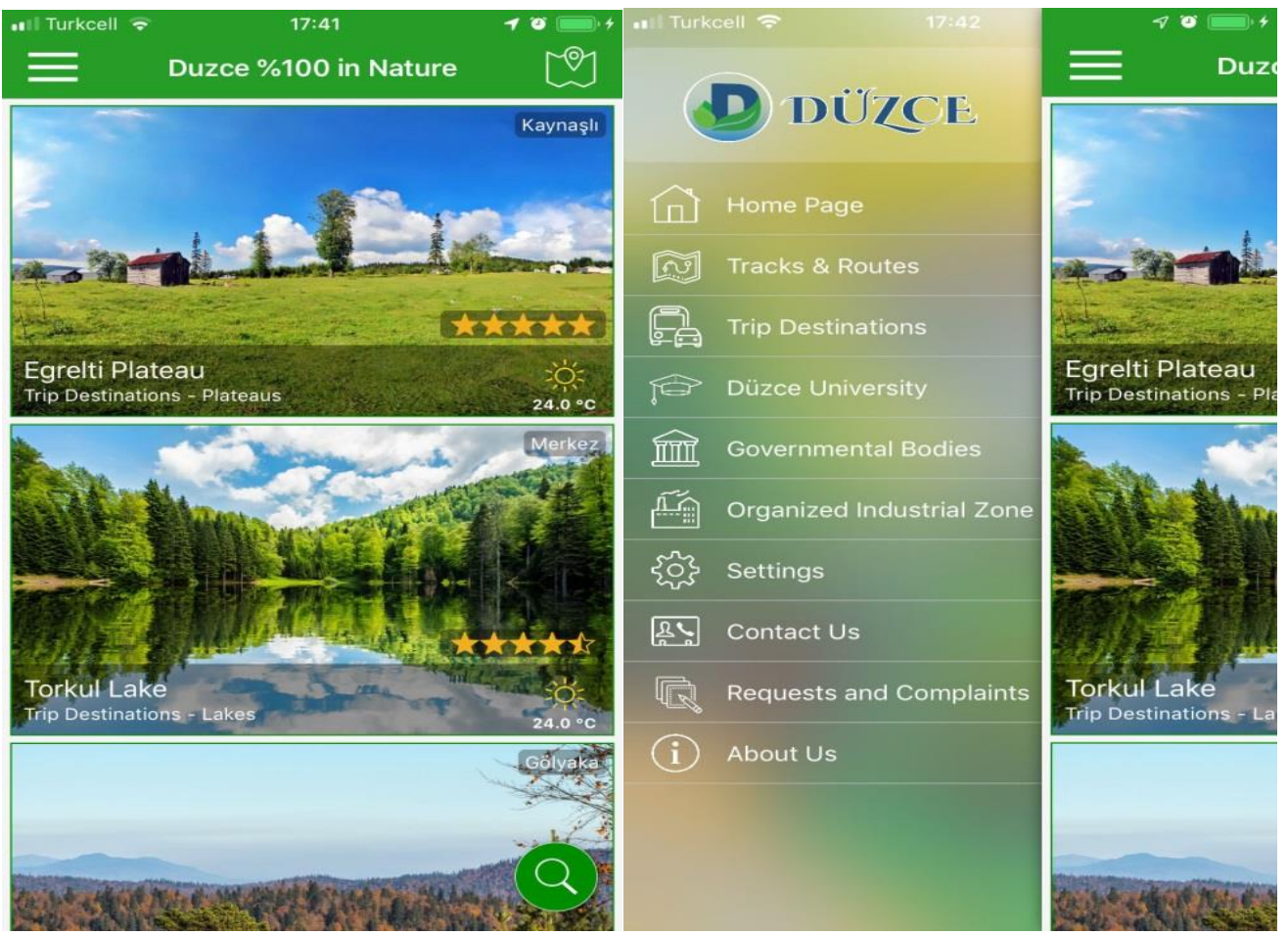

In Picture 1, when it comes to the main page of Düzce province about natural sports, it consists of trails and routes, places to visit, requests and complaints, communication, settings and about sections in the menu section. When you click on the trails and routes section and then you click on all the trails option, a menu item appears where visitors coming to Düzce for nature tourism will reach all the trails. 


\section{Picture 2: Düzce Mobile Application}

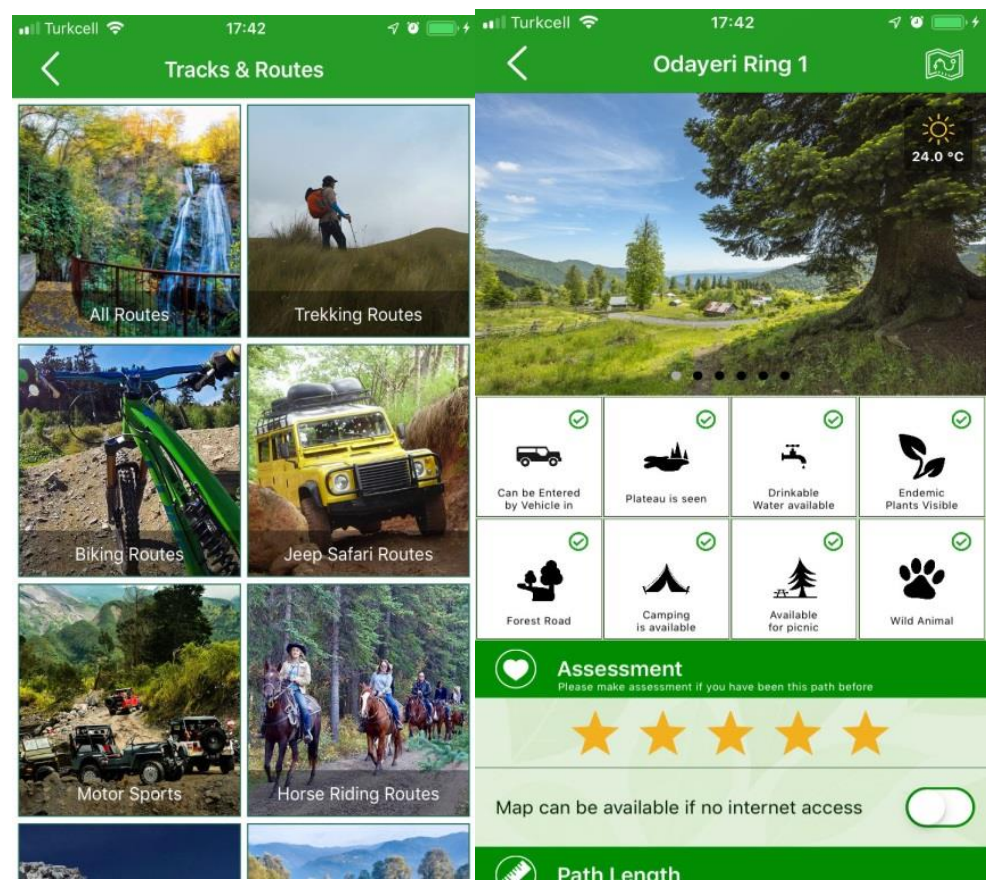

Picture 2 includes visuals showing the natural beauties of Düzce. There are a lot of pictures of many trails about Düzce such as bike trails, walking routes, and jeep safari routes, horse riding trails and climbing trails. Thanks to this mobile application, especially visitors who will come to Düzce within the scope of nature tourism will be able to find many things in this application just by downloading this application to their phone.

\section{Picture 3: Continuation of Düzce Mobile Application}

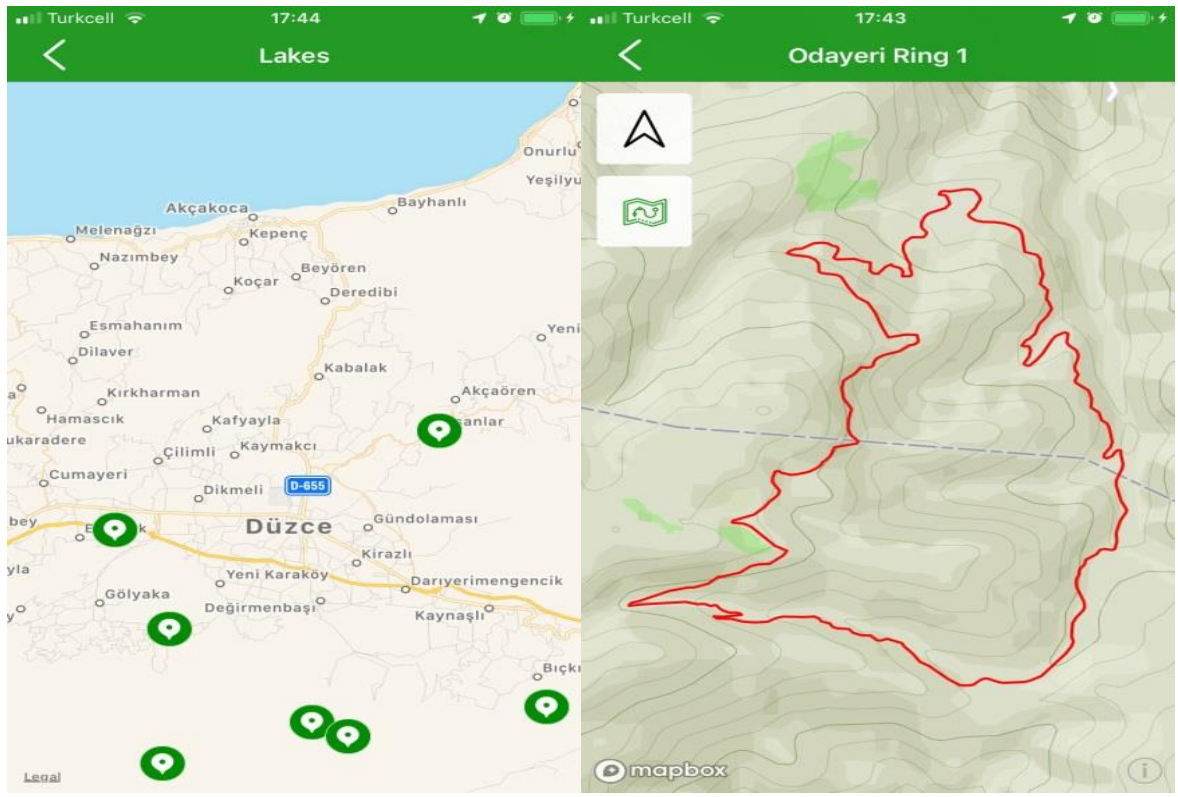


In Picture 3, in addition to the visuals of the trails of Düzce province, it will also be easy to reach these places easily by taking its image and directions on the map.

Picture 4: Continuation of Düzce Mobile Application

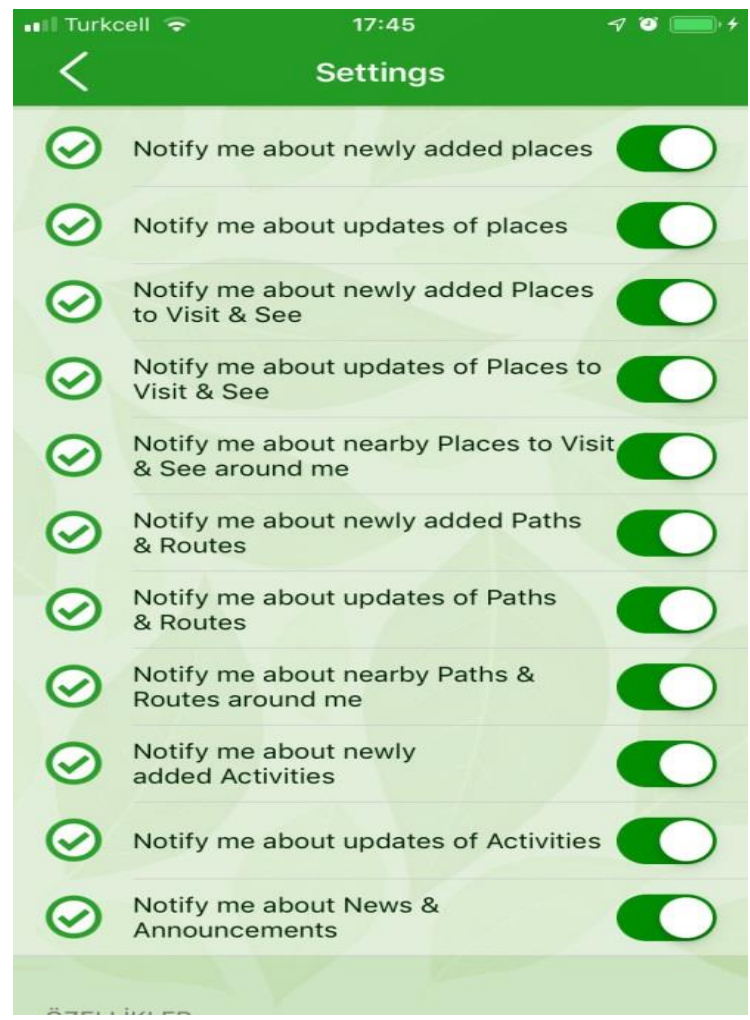

In Picture 4, it can be determined which type of notifications will be received within the application and there is a section in which your requests and complaints for destinations can be forwarded by photographing,

\section{The Method of Research}

This study examines the Düzce mobile application, which is one of the digital studies conducted for nature tourism. This program was previously created and applied to participants using this program. For this purpose, qualitative research method was preferred in the study in order to determine the attitudes of the participants using Düzce mobile application. Qualitative research is a method that examines individuals' behaviours, attitudes and perceptions in a holistic way (Karagoz, 2017: 565). However, while designing a research design; a holistic single case study (Yıldırım and Simsek, 2000) was preferred considering that an opinion was wanted to be confirmed, that there were specific circumstances and that no one had worked this subject before. Only one analysis unit was identified in this study as a requirement of a single case event design. It is employees who use the mobile application in the X Public Institution. The number of participants using the mobile application and accepting the interview is 21 in this institution. In this context, 21 people using Düzce Mobile Application were interviewed. The data of the study was obtained from the participants using the mobile application by face to face interview method. The interviews were conducted between 25.05.2019 and 30.06.2019 in line with the appointments determined by the 
employees. The responses of the employees during the interview were recorded in written by the researcher. The recorded records have been turned into written documents. The interviewed participants were coded as K1, K2, K3 ..... and K21 and these codes were included in the analyses.

In order to determine the attitudes of the participants to use mobile application, a questionnaire was prepared. This interview form prepared by Akyol (2014) was created by benefiting from his study. Before collecting data from the participants, the questionnaire was finalized by taking the opinions of two experts in the field. The questionnaire consists of two parts. In the first part, there are questions about the demographic data of the participants. In the second part, the participants are asked questions to determine their attitudes as a result of the mobile application. The questions in the semi-structured interview form were prepared according to twelve themes. Under each of these themes, common codes were determined. The data obtained were analysed through descriptive and content analysis.

\section{The Findings of Research}

\subsection{Demographic Characteristics of Participants}

When the demographic characteristics of the participants were examined, it was found that 10 participants were female and 11 participants were male. When the age groups of the participants were examined, 2 people were in the 17-23 age range; 6 people are in the 23-29 age range; 4 people in the 29-35 age range; 3 people in the $35-41$ age range; 5 people in the 41-46 age range; and 1 person was in the 46-53 age range.

\subsection{Evaluation of the Expression of the Participants for Interview Questions}

In this section, there are the codes and themes that are generated as a result of the detailed analysis of the answers given to the questions asked to the participants in the research.

Question 1. How often do you use mobile application?

Table 1: Participant Opinions on Frequency of Using Mobile Application

\begin{tabular}{|c|l|}
\hline \multicolumn{1}{|c|}{ Themes } & \multicolumn{1}{|c|}{ Codes } \\
\hline & 1.1 As needed(12) \\
1. Frequency of Using Mobile Applications (21) & 1.2 Summer Season (7) \\
& 1.3 Other (2) \\
\hline
\end{tabular}

Table 1 shows the participants' expressions regarding the frequency of using mobile applications. According to Table 1, the total number of participants is 21 , while 12 of the respondents use it when needed, 7 people in the summer period and the other 2 people stated the other option of frequency of using mobile applications as greatly.

Question 2. What aspects do you find suitable for completing the task in your mobile application? Could you tell us about the difficulties you have experienced? 
Table 2: Participants expressions to the question of 'What aspects do you find suitable for completing the task in your mobile application?'

\begin{tabular}{|l|l|}
\hline \multicolumn{1}{|c|}{ Themes } & \multicolumn{1}{c|}{ Codes } \\
\hline & \begin{tabular}{l}
\multicolumn{1}{|c|}{2.1 Trails and Routes (13) } \\
2.2 Tourist attractions (8) \\
2. Aspects suitable for you to complete the task in \\
the Mobile app you're using (21)
\end{tabular} \\
& \\
\hline
\end{tabular}

In Table 2, participant statements are seen to the question of 'What are the best aspects of your mobile application for you to complete the task? Could you please tell us about the problems and difficulties you are experiencing?'. According to Table 2, 13 people preferred touristic attractions while 8 people preferred trails and routes. While $(\mathrm{K} 1, \mathrm{~K} 12, \mathrm{~K} 16)$ declares that using is very easy, the participant (K5) mentioning the difficulties declares that tourist attractions to spend time in Düzce should be included. On the other hand, some participants (K4, K13) stated that it would be good to have walking routes, picnic and recreation areas as well as places to visit at the weekend.

Question 3. Did the Mobile application you use meet your expectations? Can you briefly mention?

When the participants' answers to the third question were examined; 20 people stated that mobile application has met their expectations and only 1 person expressed that it did not meet his/her expectations of the mobile application. The participants emphasized the fascination of the photographs (K17, K19), while (D1, K5, K13, K14) declared that the accessibility of all touristic destinations in Düzce met their expectations. have used?

Question 4. Which modules did you use most within the mobile application you

When the participants' answers to the 4th question were examined; 13 people for touristic destinations, 2 people for the trails route, 6 people use both the touristic destinations and the route stated that the route

Question 5. What aspects you didn't like within the application you used?

When the participants' answers to the 5th question were examined; the participants stated that there was nothing that they did not like in general. K9 stated that it would be good to use more photos and videos, while K21 stated that he did not like the directions application and that Google road maps created different routes on alternative routes. $\mathrm{K} 16$ and $\mathrm{K} 20$ stated that offline maps would be great if they were loaded at one time.

Question 6. Was it easy to use your mobile application in order to achieve the goal? Or was it difficult? 
Table 3: The expressions of participants to the question of Was it easy to use your mobile application in order to achieve the goal? Or was it difficult?

\begin{tabular}{|l|c|}
\hline \multicolumn{1}{|c|}{ Themes } & Codes \\
\hline 6. Was it easy to use your mobile application in & 6.1 Easy (21) \\
order to achieve the goal? Or was it difficult? (21) & 6.2 Difficult (0) \\
& 6.3 Other (0) \\
\hline
\end{tabular}

All participants stated that the mobile application they use was easy to use.

Question 7. Do you think the mobile application you use is secure? What are the basic criteria for the formation of these concepts at you?

Table 4: Participant Opinions for the question 'Do you think your mobile application is secure?'

\begin{tabular}{|l|l|}
\hline \multicolumn{1}{|c|}{ Themes } & \multicolumn{1}{c|}{ Codes } \\
\hline 7. Do you think your mobile application is secure? & 7.1 Yes (12) \\
(21) & 7.2 No idea (9) \\
& 7.3 No (0) \\
\hline
\end{tabular}

In Table 4, you can see participant statements for the question 'Do you think the mobile application you are using is secure?'. According to Table 4, 12 of the participants found the application safe and 9 of them stated that they had no idea whether it was safe or not.

Question 8. In which platform are you using the application you are using?

When the answers given by the participants regarding the 8th question were examined; the majority of the participants stated that they used the application via IOS (Iphone) and that after the IOS (Iphone) the application was mostly used via ANDROID (Mobile). Although the number of users using IOS (Tablet) is small, it is stated by the participants that the application is also used here.

Question 9. Was the performance (speed, etc.) good in the Mobile application you were using? Do you wait a long time in performing one task and moving to another?

Table 5: Participants' expressions for the question of Was the performance (speed, etc.) good in the Mobile application you were using?'

\begin{tabular}{|l|l|}
\hline \multicolumn{1}{|c|}{ Themes } & \multicolumn{1}{c|}{ Codes } \\
\hline & \multicolumn{1}{|c|}{ 9.1 Fast (5) } \\
9. Was the performance (speed, etc.) good in the & 9.2 Slow (1) \\
Mobile application you were using (21) & $\begin{array}{l}\text { 9.3 Normal (15) } \\
\text { 9.4 Other (0) }\end{array}$ \\
\hline
\end{tabular}

In Table 5, you can see participants' expressions for the question 'Was the performance (speed, etc.) good in the Mobile application you were using? Do you wait a long time in performing one task and moving to another?'. According to Table 5, participants stated that overall speed was normal, they did not experience any problems during the transitions between modules, only one person expressed that it was slow and needed to be faster. 
Question 10. Were offline maps routing and information sufficient in your mobile application?

Table 6: Participants' expressions for the question of 'Were offline maps routing and information sufficient in your mobile application?

\begin{tabular}{|l|l|}
\hline Themes & Codes \\
\hline 10. Were offline maps routing and information & 10.1 Yes (17) \\
sufficient in your mobile application? (21) & 10.2 to be developed (3) \\
& 10.3 Other (1) \\
\hline
\end{tabular}

In Table 6, it is seen the participant statements about the question 'Was the offline maps routing and information sufficient in your Mobile application?'. According to Table 6; the majority stated that the maps were sufficient to guide and inform. On the other hand, participants using the expression 'to be developed' have stated that the maps should be downloaded at one time, more map information could be added and the maps should be more specific. The participant who selected 'other' stated that he did not use the maps.

Question 11. Did the mobile application you use satisfy you visually? Evaluate in terms of colour harmony, font size, readability?

Table 7: Participants' expressions for the question of 'Did the mobile application you use satisfy you visually?'

\begin{tabular}{|l|l|}
\hline Themes & Codes \\
\hline 11. Did the mobile application you use satisfy you & $\begin{array}{l}11.1 \text { Yes (19) } \\
11.2 \text { No (2) }\end{array}$ \\
visually?? (21) & \\
\hline
\end{tabular}

In Table 7, you can see the participants' expressions for the question 'did the mobile application you use satisfy you visually? Evaluate in terms of colour harmony, font size, readability. According to Table 7, the participants stated that they were satisfied with the application and those who were not satisfied wanted to use their own colour themes and stated that it was better to have a colour combination.

Question 12. Is the mobile application enough for you? What other features would you like to include?

When the answers given by the participants regarding the 12th question were examined; the number of participants stating that the mobile application is sufficient is quite high. The participants who made suggestions for the mobile application made the following suggestions: It was suggested that the menu of globalization routes should be added, some additions should be made for current situations, it would be better to have local product promotion and not to go back to pass to another page.

\section{Results and Suggestions}

Technological and innovative improvements in recent years are of great importance in tourism sector as in all sectors. Especially in the marketing and sustainability of tourism, mobile applications have been developed to reach customers.

In addition to the locational advantage of Düzce, it is possible to see many tourism types together. It is a tourism destination where nature lovers prefer especially 
with its natural beauties. Mobile applications have been developed in order to increase this potential further and to get more shares from the tourism market in the country and around the world, especially from the types of tourism made in nature. The mobile applications of Düzce province have been revealed as both a different dimensioning and remarkable feature in terms of introducing Düzce.

In the light of data achieved by face to face interview technique, it was understood that 10 participants were female and 11 participants were male, the participants were mostly in 23-29 and 41-46 age range. When the opinions of the participants using the mobile application were examined, they stated that this application was very easy, that it met the expectations of easily accessing all the tourist attractions of Düzce and that the photos in the application were impressive. In addition, the participants stated that the mobile application is suitable for the purpose and that the maps to guide / inform are sufficient.

In 2014, Akyol conducted a research to find out the Participants' opinions about the user prefaces of two different mobile applications in accordance with certain principles. At the end of the study, all users mentioned that the performance and speed of mobile applications are directly proportional to the speed of the internet connection. No user stated in their replies that mobile applications were unsafe. Akyol (2014) showed similarities between the findings of the study and performance and safety findings in the mobile application. Sanlız et al. (2013: 258) carried out a research on the agencies for the use of mobile marketing applications in the tourism sector. Authors has assertion like that 'Agencies with a professional background ensure by using the power of its domestic travel agency brand in digital platforms that consumers trust in tourism and online applications and prove this trust with the level of approximately $67 \%$ loyal customers they provide in all tourism services'. In this study, the question of 'Do you think the mobile application you use is secure?' was directed to participants. $57 \%$ of the respondents answered 'yes' and the rest did not express their opinions. However, there are no participants who answered 'no'. It can be stated that the sense of trust in the mobile applications indicated by Sanlıoz et al. (2013) is similar to the finding that the mobile application is in a secure structure in this study. Along with this, the participants using the mobile application made some suggestions about this application. There suggestions are;

- There should be touristic destinations to spend time in Düzce,

- It is necessary to define the walking routes and the destinations to go to on picnic and for promenade at the weekend.

- The possibility of downloading the maps at once,

- More map information should be added and the maps should be more specific,

- A globalization routes menu should be added,

- Local products promotion should be added,

- It would be better not to go back again to switch from one page to another.

It is important for the individuals particularly who will participate in the naturebased tourism type to investigate their destination beforehand and determine the route accordingly. In recent years, mobile applications developed for tourism types based on nature provide a great convenience to nature tourism participants. Düzce mobile application created within the scope of nature tourism of Düzce works on Android and iOS platforms. For the application, walking routes, cycling routes, jeep safari routes, Motor Sports routes, Horse riding trails, Climbing and Paddle routes can be reached under the Trails and Routes menu. If the "Let Map Run without Internet" tab is activated in any route from Trails and Routes, it will load the map in the region where 
the course is located to your mobile. Thanks to map loaded to the mobile, Trails and Routes can be used without internet, where the GSM network cannot send signals. In the future, different and new menus (food, accommodation, etc.) can be added to this mobile application and it can be developed more. (Actually, this section is active, organizations serving accommodation and taste are required to enter data as a member. Contract sample for commercial organizations have been prepared. It is important that commercial organizations are visited and informed on site for the accuracy of the data entered and the continuation of activities of the commercial organization. It is required to make an extension each year.

Mobile applications both prevent loss of time and provide the right information by providing a combination of everything that can be learned about a province. Particularly holiday lovers will be able to reach most of their visitors from the internet as there are internet environment among the first places they will apply for destination choices within the scope of alternative tourism. On the other hand, creation of each province's own mobile application can provide important opportunities in terms of creating awareness and being preferred.

Application sends various notifications, while wandering around Düzce province. For example, while passing through Kaynaslı district, 'Gırgın Meadow is $5 \mathrm{~km}$ away from you'. Application also sends notifications about the activities to be done.

\section{References}

Akoğlan, K. M.,\& Bahçe, S. (2012). Özel İlgi Turizmi (2. Baskı). Ankara: Detay Yayıncılık, s. 169- 199.

Akyol, G. (2014). Mobil Uygulama Ara yüzlerinin İncelenmesi Üzerine Bir Çalışma. ISITES2014, Karabuk.

Aslan, B. \& Aslan, Y. , F. (2013). "Mobil Programlamanın Önemi Ve Bir Müfredat Önerisi", 3.Uluslararası Meslek Yüksek Okulları Sempozyumu, s. 86.

Durmaz, C., Bulut, Y., \& Tankuş, E. (2018). Sanal Gerçekliğin Turizme Entegrasyonu: Samsun'daki 5 Yıldızlı Otellerde Uygulama. Turkish Journal of Marketing, 3(1), 32-49.

Gülbahar, O. \& Yıldırım, F. (2015). Marketing Efforts Related to Social Media Channels and Mobile Application Usage in Tourism: Case Study in Istanbul. Procedia Social and Behavioral Sciences, 195, 453 - 462.

Karagöz, Y. (2017). SPSS ve AMOS Uygulamalı Bilimsel Araştırma Yöntemleri ve Yayın Etiği(1. Baskı). Ankara: Nobel Yayıncılık,

Korkmaz, M. (2001). "Orman Kaynaklarında Doğa Turizmi ve Av turizmi Etkinliklerinin Ekonomik Çözümlemeleri”, Yayımlanmamış Yüksek Lisans Tezi, İstanbul Üniversitesi, Fen Bilimleri Enstitüsü, İstanbul.

Irmanti, D., Hidayat, M. R., Amalina, N. V., \& Suryani, D. (2017). Mobile Smart Travelling Application For Indonesia Tourism. Procedia computer science, 116, 556-563.

Özkan, B. M. (1995). "Eko turizm Politikası", İnsan ve Çevre Dergisi, , Eylül Sayısı, Ankara.

Serra, L. C., Carvalho, L. P., Ferreira, L. P., Vaz, J. B. S., \& Freire, A. P. (2015). Accessibility evaluation of e-government mobile applications in Brazil. Procedia Computer Science, 67, 348-357.

Sürücü, Ö. \& Bayram, A. T. (2016). Mobil Pazarlama ve Turizmde Mobil Teknolojilerin Kullanımı. Journal of International Social Research, 9(42). 
Şanlıöz, H. K., Dilek, E. \& Koçak, N. (2013). “Değişen Dünya, Dönüşen Pazarlama: Türkiye Turizm Sektöründen Öncü Bir Mobil Uygulama Örneği”, Anatolia: Turizm Araştırmaları Dergisi, 24 (2), s. 250 - 260.

Yıldırım, A. \& Şimşek, H. (2000). Sosyal Bilimlerde Nitel Araştırma Yöntemleri, İkinci Baskı, Ankara: Seçkin Yayıncılık.

Zelan, Z. (2015). "Dijital Dünya, Sosyal Medya Ve Fikri Haklar", http://inettr.org.tr/inetconf19/bildiri/91.pdf, (Erişim Tarihi, 12. 11. 2018). 